Reviews

\title{
Beatrice Marovich
}

\section{"Fear of the Crocodile is the Beginning of Wisdom?"}

Dan Wylie, Crocodile. London: Reaktion Books Ltd., 2013. 222 pp. £ 12.95; \$19.95.

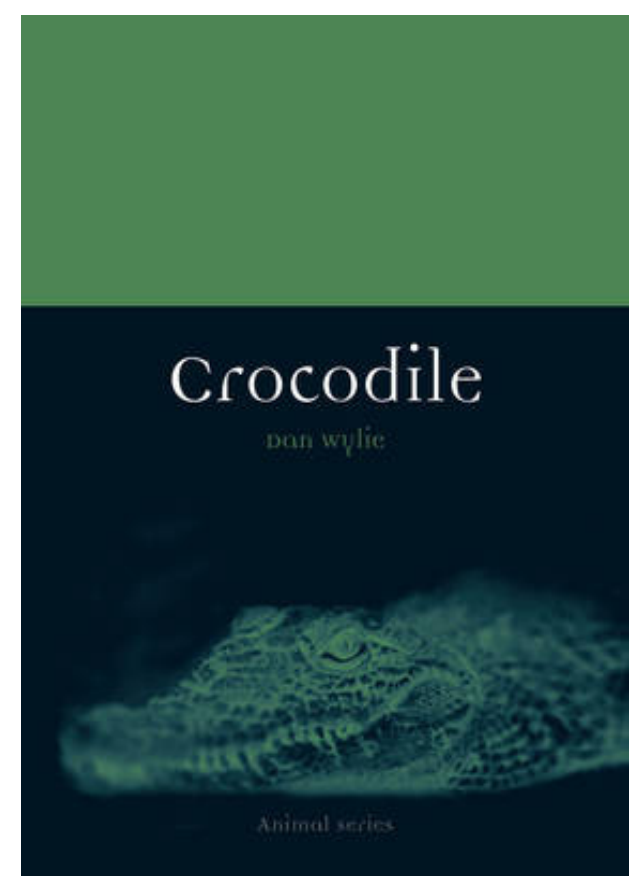

Late in his book Crocodile, Dan Wylie briefly references the fact that Sigmund Freud's theory of the uncanny - Das Unheimliche, that paradoxical force in the psyche that both attracts us to, and repels us from, an object - was at least partially inspired by a crocodile tale, "The Inexplicable," by L.G. Moberley. This connection between crocodiles and the uncanny seems rather coincidental - tucked away, as it is, in the final chapter of this dense little book. But if, for Freud, the uncanny was a reminder of our own repressed impulses, it appears to me that the crocodile becomes a reminder, for Wylie, of other repressions. Chiefly, perhaps, the crocodiles of Crocodile seem to stand as reminders of a repressed (particularly pre-modern) fear of and attendant reverence for this ancient creature.

To be sure, this book - like others in the Reaktion Books animal series - is something of a survey. Wylie covers a lot of territory and focuses not only on cultural history, but on natural history and species differentiation among crocodilians. He confesses, from 
the outset, that the book is somewhat misleadingly named, as it topically treats not only "proper" crocodiles, but alligators, caimans, and gharials as well. The method Wylie sets up for surveying the broad and complex history of the crocodilian - one that extends into most regions of the world - is to explore their stories by continent. He begins with Africa (where this history is arguably richest) and ends with Europe (where the presence of the crocodilian has been only more recently mediated through trade routes). Casing such diverse geographical terrain gives Wylie plenty of material to cover: from ancient history, to archaeology, folklore, costuming, art, medicine, scientific research, conservation, and pop culture. The content of Crocodile is almost encyclopedic in its scope, and is a fascinating archive of detail.

Yet there is a thread that Wylie illuminates in his introductory pages. He finds that, "surprisingly often, crocodilians have been worshipped, appealed to, represented and treasured, albeit almost always with a tinge of fearfulness" (8). Thus this fear, and how it is eventually transformed, from a "fear of crocodiles to fear for them" (8), becomes an important theme of the book. Those familiar with theories such as Rudolph Otto's "idea of the holy" - exploring the entanglement of holiness with fear, reverence, and awe will be unsurprised that Crocodile often segues into matters often deemed spiritual or religious.

Wylie speaks about the importance, in North and West Africa, of the crocodilian in divination, giving them what he calls a kind of "mystical significance." Particularly important in this context were gastroliths - stones from the stomachs of crocodiles. Among the Thonga of southern Mozambique, says Wylie, "if a chief were treated with suitable drugs, he could swallow a gastrolith, whence it would warn him of his death" (19). Wylie also addresses the Egyptian god Sobek (or Sebek, or Suchos) - a virile divine who was held in special esteem in regions along the banks for the Nile, often depicted with the rays of the sun god Ra behind him. The crocodilian in this opening section of the book seems to take on a kind of spiritual power and potency.

In the discussion that follows, of Central \& Southern Africa, Wylie speaks not only of the "magical" associations that crocodilians often have with witchcraft. Additionally, he notes, this is a region where it has become especially apparent that "associating crocodiles with spiritual power bleeds readily into political power, both symbolically and actually" (67). Although Napoleon himself was apparently given the moniker of "the Corsican crocodile" (164), Wylie here lists a host of African "strongmen" whose symbolic and actual association with the crocodile seems designed to increase their public sense of prowess and power. Idi Amin, of Uganda, was alleged to keep

Humanimalia: a journal of human/animal interface studies

Volume 7, Number 1 (Fall 2015) 
crocodiles on his property for the express purpose of feeding them the bodies of his political opponents. Robert Mugabe has embraced the symbol of the crocodile as a sign of his own political power (67). And South African apartheid-era president P.W. Botha used the nickname "Big Crocodile" to capture "his reputation for political ferocity" (71).

In South America Wylie finds a rich diversity of caiman species, but less "crocodilian lore" of great and enduring cultural significance. In Central America, however, he finds a Mayan deity Itzem $\mathrm{Na}$ - a god of the elite - whose "heavenly guise" was that of a huge alligator (100). In North America, where alligators once inhabited a range that ran from the Florida Keys as far north as Maryland, Wylie does not find much notable crocodilian iconography. But he does note that, "like crocodilians elsewhere" the American alligator's physical power came "to embody both ferocity" and, in different way "deceit" (108).

Wylie does find more mythical lore in Australia where, he says, crocodilians seem to have occupied a place of importance in creation myths. This place of reverence, however, does not obviously translate into attitudes of respect. In the Kimberley region Wylie finds an origin myth in which crocodiles - attempting to steal the powerful fires that were meant for humans - are eventually gutted and stabbed as a cosmic revenge (121). Wylie acknowledges that this sort of mythology does seem to hide an air of anger or grievance. But still, he argues, the postures revealed in these creation myths are "markedly distinct from that of European settlers on the continent," for whom "fear and disgust" eventuated in "slaughter and commercial exploitation" (122). Key for Wylie here, it seems, is the combination of slaughter with colonial commerce and global capital. In this sense, perhaps, he echoes thinkers such as the Australian philosopher Val Plumwood who is attacked by a crocodile and invests this encounter "with almost religious force." Plumwood, as Wylie presents her in this narrative, does indeed find a kind of fear and revulsion in her crocodile encounter. But she differentiates this from the revulsion that is more typical of those from the modern west whose treatment of the crocodile is not only "rapacious" but "upstart" (127). It lacks history, context, legitimacy. Pre-modern Australia, then, seems to offer an illumination of what colonialism, industrialization, and capitalism lack in their engagement with crocodilians.

In India, Wylie finds an example of a modern, global, organization that is pulling from the ancient iconography of crocodilians in an attempt to protect it. Species of gharial, he

Beatrice Marovich - "Fear of the Crocodile is the Beginning of Wisdom?" 
reports, are often sought after in India - their eggs are collected for medicinal purposes, and the long snouts of the males are held to have aphrodisiacal properties. Recently, the World Wildlife Fund has tried to "enhance respect" for these creatures by "distributing flyers that quote the Bhagavadgita on the importance of the gharial in the sermons of Lord Krishna" (150). Aspects of religious tradition are being actively recruited for the crocodile cause.

In Europe - where the crocodilian is not native - Wylie finds little evidence of this otherwise ever-present fear and reverence for the crocodilian, beyond the attitude of cold exploitation generated by scientific modernity. As he puts is, "imperialist Europeans regard crocodilians everywhere as grotesque, unnervingly sneaky and formidable, and therefore as primary targets for their rapidly developing armaments" (168). And yet, he does make note of the presence of crocodilians in illuminated manuscripts, and as (often troubling) emblems in Christian allegories penned by monastics (154). Additionally, he makes note of the fact that crocodile skins and skeletons were sometimes displayed - as if gargoyles - on the cornices of churches (161). Their corpses also appeared as figures of awe on the ceilings of early modern "cabinets of wonder" (164). That is to say, there is evidence that the European fear of the crocodilian is not religiously irrelevant or without reverence of a sort. But it seems to lack meaning, or validity, in this account.

In the end, there is something of a tone of lament to Crocodile. Citing the devastating statistics of the decimation of crocodilian species across the globe - as well as the sometimes encouraging attempts to restore these populations - the conservation of crocodilian species is obviously a concern that is just below the surface of this text. And the responsibility of, especially, European and American imperialism and industrialization in this decimation is impossible to deny. While Wylie is explicitly clear that the tools of technological modernization are largely responsible for such phenomena, the suggestion also seems to stir just below the surface of his argument that perhaps there is a kind of repressed awe or fear-tinged reverence for the crocodile whose lack is also partly to blame for this devastation.

There is, certainly, something disruptive about crocodilian iconography when we contemplate it from a contemporary American perspective. To imagine a crocodile fused with the figuration of a divine challenges a perspective on crocodilians that may have been unduly shaped by Crocodile Dundee or the performative stylings of a "crocodile hunter" like Steve Irwin. It is odd, perhaps, from our contemporary context to consider the crocodile as an ancient creature who has long inspired awe and

Humanimalia: a journal of human/animal interface studies

Volume 7, Number 1 (Fall 2015) 
reverence. What is less clear, at least to me, is whether reverence and awe are things that stand any chance of combatting the commercial and industrial threats to existence that crocodiles face, today. Awe and reverence - even the sorts tinged with fear - are not necessarily correlated with respect or a sense of ethical obligation.

Beatrice Marovich - "Fear of the Crocodile is the Beginning of Wisdom?” 